(C) 1987 ISI.J

\title{
深絞り加工における速度効果
}

\author{
花 木 香 司*・加 藤 健 三*2
}

\section{Speed Effects in Deep Drawing}

\author{
Koji Hanaki and Kenzo Kato
}

\section{1. は じめに}

プレス速度の暹い液厓プレスによる製品が機械プレス の製品と片を謟べて今も其你している事実はプレス成形 に及ぼす速度の影響の人きさ，複雑さを示唆している。 もちろん，製品によつてはどうしても複動プレスでなく てはならないとか, 大きな成形荷重が必要とか等の他条 作によつて液川:プレスが利用される事情を差し引いて考 える必要があるが. 川:延機の高速化ほど，プレス機の高 速化が声高に川卟れなかつたのも，この辺の事情を反映 しているのであろう。しかし製品の中には経験的感覚に よつて，あるいは管性的にプレス機械が選扒されている ケースも少なくない。低速成形のみを川としてきた製品 の中には，現湬の本質から商速でも川であり，いゃむし 万高速の广が好ましい場今も少なくないと思われる。も ちろん，その塨苓は生產性の立場からも高速成形が推奨 される。このように適切なプレス速度の選定は極めて重 荌である。

また，加ににはり操業で処理しうる問題もあれば，怣 験公で解明せざるを得ない問題もある，後者の場命，実 騃で得られた絬果と飐操業の絬果とが良い対蚛を示さな

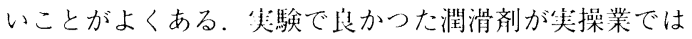
良くなかつた等の例がそうである。このような時には現 場プレスと験プレスとの速度が一致しているかどうか まず注意されねばならない。ささらに，速度効果の研究は 笑操業で生じている種々の現象の本質を理解する上でも 有効なアプローチとなる.

ところで,プレス加ににおいて成形された板金製品は, せん断，曲げ管の加にを除くとその変形状態から張出し 変形と深絞り変形とに人別される。㭎1の（a）のよう に素枚の衣陌積を増加させ素极金属の伸びによつて容器 を造るのが振出し成形であり，（b）のように谷器の底 となる部分を除く奖板の外夙部をダイス公内に絞り込ん
で谷器とするのが深絞り成形である. 結果として張出し 罍器は肉厚が薄く, 深絞り谷器は壁部の肉厚が厚い。た いていの板金製品はこれら画変形が同一製品中に其你し ている複令成形品である場合が多い．代表的なプレス製 品である自動車の外板部の主要な全パーツについて変形 状態が調査され，まとめられた結果が闵 $2^{11}$ に示されて
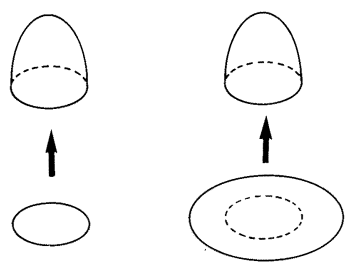

(a)張出 し変形 (b)哚絞り変形

网 1 張出し変形と深絞り変形による同一形状製品

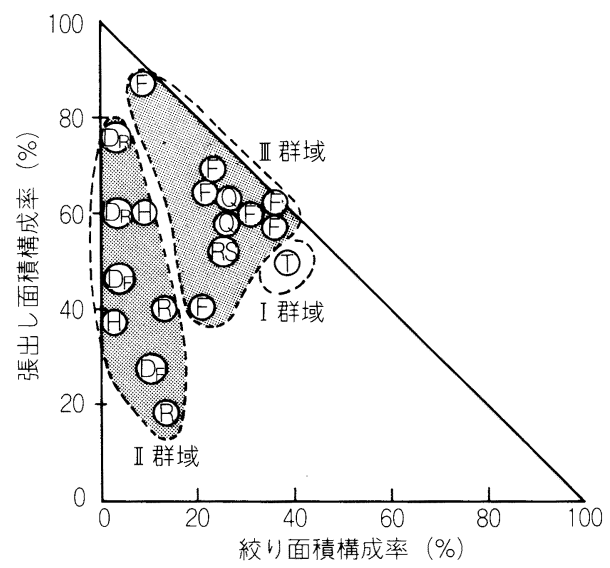

汹 2 成形の群城脳 ${ }^{11}$

岹利 61 年 8 月 21 月受付 (Received Aug. 21, 1986) (依頼技術資料)

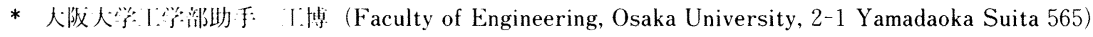

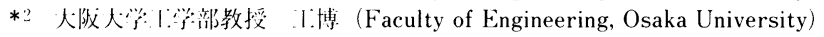
Key words : deep drawing ; rapidity ; bydraulic press ; productivity testing ; experience configuration ; parameter theory; autobody ; review. 
いる。あるパーツの全面積に占める深絞り変形の割合を 横軸に, 張出し変形の割令を縦軸に取つて, そのパーツ の変形状態が示されている. 丸印内の記号はパーツ名で, 例としてRはリヤドア， Tはトランクである。いずれの パーツも汹の左上半域にあり, 張出し変形成分の割令が 勝つていることを示唆している. しかし成形性，すなわ ち割れ等が問題となつたパーツは吕群域の物であり画変 形の比率より, 深絞り構成率の絶対值が重要であること を示唆している。このように標題で示される課題は深絞 りをプレスと読み変えても良い重要な課題である.

\section{2. 現象論的解明}

COUPLAND 達はこの課題と本格的に取り組んだ最初の 人達である2)。それまでは部分的な報告が多く，それゆ え全体像が掝めず逆に混乱を助長していた．破断するこ となく絞り达み得る最大素板直往を使用ポンチ值径で除 した值, すなわち深絞り成形性の指数 $L D R$ が平頭ポン チでは正の速度依存を示し, 球䫓ポンチでは負の速度依 存を示す図 3 の結果を彼等は報告した。间 4 はポンチ荷 重・ポンチストローク曲線の素板㨁径による変化を示し た模式四で, 直径の増加と其に最大絞り力が増し, 破線 で示す破断力に最大絞り力が達する素板㨁径から LDR が決定される. COUPLAND らは同一直径素板の最大絞り 力, 加工限界洎径素板の破断力の各条件における比較等 によつてこれら両ポンチによる速度効果を現象論的に解 明している. LDR, 破断力, 最大絞り力の 3 特性の速 度依存性から深絞り加工の速度効果が初めて論じられた のである。ところで汹 5 は筆者らの結果 ${ }^{3)}$ を示したもの

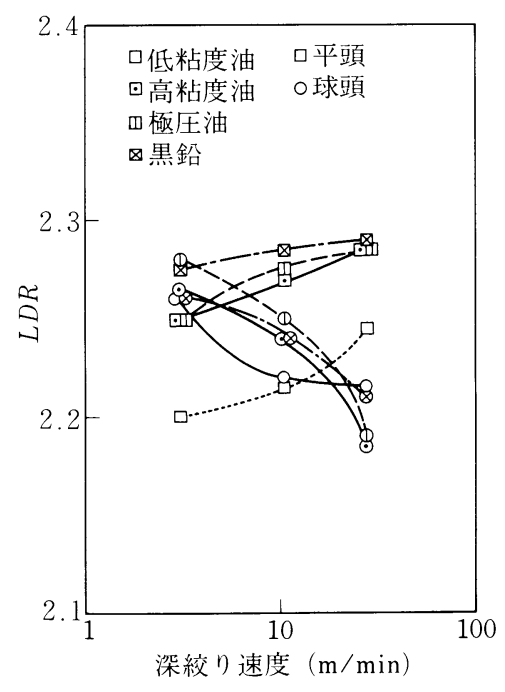

汹 3 深絞り速度による LDRの変化 (COUPLAND らの結果)
で汹 3 の速度効果とはかなりその様相が異なつている. 汹 5 の $0.05 \sim 1 \mathrm{~m} / \mathrm{min}$ で, 球顥ポンチでは $L D R$ が増し ており，平䫒ポンチでは一走である。このような違いは 潤滑剤の違いもさることながら主としてダイス有半待, ポンチ肩半径等のI具諸元の違いによる．尤験条件が違 えばいろいろな結果が得られそうであり，現尖に得られ るため, 速度効果の研究は踈んじられてきたといつて艮 い.そこで，まず速度効果を現集学的に把挃するために 筆者らは㘠 6 で示すようにポンチ荷重・深絞り速度汹の 中に 3 特性を書き込み，速度効果を分類した。作闪のた めの条件は（1）同‥速度で人きい素权の最人絞りカは 小さな素板のそれより大きい，（2）间一速度で表した 破断力は最大絞り力の限である，の元つである。忔の 実線， $D_{1}, D_{2}, D_{3}, \cdots \cdots$ は素板陧径がそれぞれ $D_{1}, D_{2}$, $D_{3}, \cdots \cdots \cdot$ 素板の各速度に扔ける取大絞り力を結んだ もので, 等径素板最大絞り力線ともいうべきであるが以

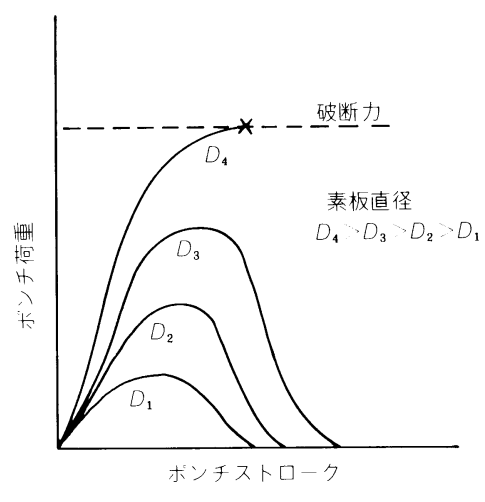

汹 4 深絞り加にに扔ける荷重・ストローク曲線の 素板淔径による変化と加1限界 (LDR)

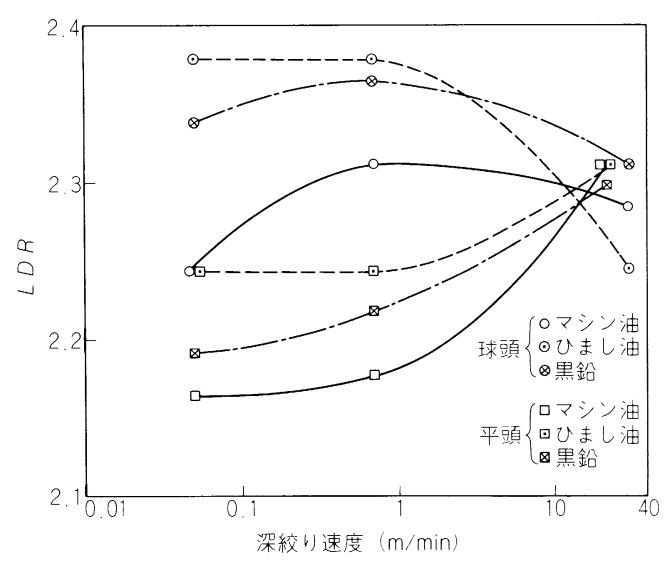

汹 5 深絞り速度による LDR の变化(筆者らの 結果) 


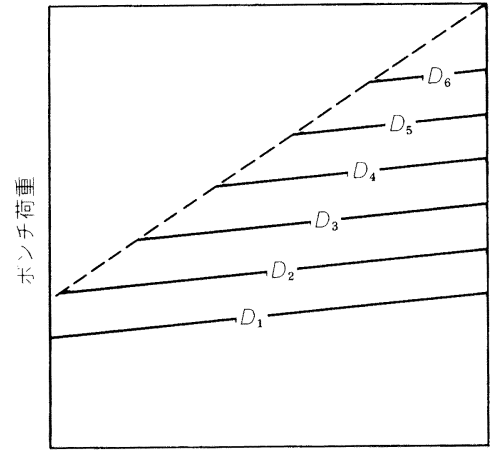

深絞り速度

汹 6 ポンチ荷重・媣絞り速度洞に㧍ける $L D R$, 破断力, 最大絞り力の関係 (……破断力, 一一最大 絞り力）

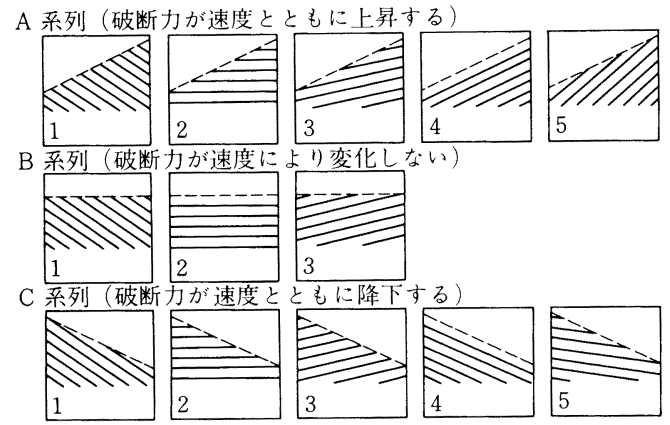

汹 7 ポンチ荷重・深絞り速度汹で考えられる可能 な速度効果のタイプ

後最大絞り力線と称する， $D_{1}$ 等の記号を添えなくとも 上の実線は，下の実線の素板直径より大きい㨁径の素板 の最大絞り力線であることは自明であろう. 破線は速度 による破断力を示した破断力線である，速度とともに破 断力線との父点をなす最大絞り力線は上昇しているか ら，この汹では $L D R$ が速度と其に上昇するケースであ る．条作（1），（2）を満たす速度効果の全夕イプを示 したのが汹 7 である. 破断力の速度依存性によつて 3 系 列に区分した。速度とともに $L D R$ が上昇するのは $\mathrm{A}-1$, $\mathrm{A}-2, \mathrm{~A}-3, \mathrm{~B}-1, \mathrm{C}-1$ である. 筆者らの平頭ポンチの 結果はどの潤滑剂でも破断力が速度とともに上昇する $\mathrm{A}$ 系列で, COUPI.ANI) らの黑鉛潤消を除く平頭ポンチの結 果はいずれも速度とともに破断力は劣化するが, LDR は上昇する C-1 である. 筆者らや CouPLAND らの結果に 引用されない $\mathrm{A}-4, \mathrm{~A}-5, \mathrm{~B}-3, \mathrm{C}-4$ 等は単に概念的な タイプでなく，ポンチ頭部には B-1 あるいは B-2 で使 用したポンチ形状と潤滑剤を,フランジ側には A-3,
A-4，A-5 いずれかの潤滑剤を塗付して樑絞りすれば B-3 が得られる。筆者らの球頭ポンチでは, $0.05 \sim 1$ $\mathrm{m} / \mathrm{min}$ の間で $\mathrm{A}$ 系列, 1 $30 \mathrm{~m} / \mathrm{min}$ の間で $\mathrm{B}$ 系列と二つ のタイプからなるように，実際の速度効果は汹７で示す 13 種の基本夕イプの適当な組合せにより説明される.

なお荷重低下によるダイス摩耗の軽減というメリッ 卜，一方製品の不良率が増すというデメリットのある ケース，すなわち速度増加により荷重が低下すると同時 に $L D R$ も低下するというケース，破断力は增すのに $L D R$ は低下するケースなど興味ある事例の存在をこの 分類网は示唆している.

\section{3. 応力波と材料の変形}

机の上に置かれた物の上端を掝んで持ち上げるとその 動きが徐々に下部に伝わり間をおいてその下端が机から 離れる現象を目撃した人は誰もいない, 上端の動きはあ つという間に下端に伝えられ我々にはその物が一体とな つて動いたとしか見えない.しかし応力波の伝播速度は いくら早いといつても有限であるため上端での動きが恐 ろしく早いと下端の動きがそれに付いていけなくなり， 上端は上方に変位しているのに下端は机についたままと いう状況が顕著になり，上端部に伸び歪みが顕在化して くる。そしてますます上端に歪みが局在化し，かつ大き くなり，下端は何の拘束も受けていないのに力の作用点 である上端が破断するに至る。衝撃破断問題を足性的に 記述すれば上のようになる，理論による解明は今なお不 十分なままである ${ }^{4)}$. 衝撃問題に重要な力の作用点の加 減速に触れず，変位の伝播方程式を解くに当たつては境

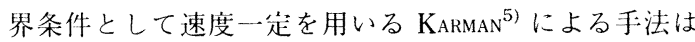
現実的とは思われない。解かれた臨界衝撃速度の実験に よる確認もあいまいである，ともあれ実験による值 ${ }^{6)}$ 臨界衝撃速度としてもクランクプレスによるプレス速度 程度の打撃では衝撃变形の問題を考える必要は無い。本 来, 脆く，それゆえ力の作用点での不均一変形に敏感で 拀うおうにして被打撃点で破壊しやすい材料が日常多く 見られるためにあたかも衝撃問題が身近な問題であるよ うに錯覚されやすい.まずは材料の問題，材料の歪み速 度依存性が問われなければならない。

金属の変形の素単位というべき転位の運動は熱的に活 性化される過程であるが故に温度すなわち速度の材料特 性に及ぼす影響は重要である。リューダース带あるいは それに関与する下部組織等が複雑な熱活性化過程である $\mathrm{C}, \mathrm{N}$ 元素を固溶する炭素鋼は, 微妙なところで複雑な 速度依存を示す7)ので注意がいるが，普段プレスしない 金属それも BCC や HCP 結晶構造の金属をプレスする 以外はクランクプレス程度の速度での伸び不足による製 品不良を心配することはない.

歪み速度依存指数 $m$ 值は, 超塑性では結晶粒界の粘 弾性挙動を反映し, 普通の金属では粒内の転位の運動の 
速度依存あるいは熱活性成分の大きい転位のクロスス リップの容易さを反映する ${ }^{8)}$ なと，そのよつているメカ ニズムは種々さまざまである。しかし超塑性状態のみな らず普通金属の引張試験におけるくびれ伸びをも $m$ 值 は良く表す ${ }^{9)}$. もち万ん， $m$ 值が求められていれば液圧 から機械プレスにその材料を供した時の変形抵抗の上昇 率を推測できるのはいうまでもない。超塑性材料では $m$ 值自身が歪み速度依存を示し, 低速で $m$ 值が大で高 速で小となる。冷延鋼板では歪み速度とともにくびれ伸 びが増すという報告 ${ }^{10)}$ からするとその $m$ 值は歪み速度 とともに増していると思われる。

网 8 は 5 種類の板金材について深絞り性の指標となる $r$ 值の歪み速度依存を示す。室温に打ける歪み速度の アップは室温以下での低温引張りと見なせる故に新たな すべり系が活動するとは考えられず， $r$ 值の変化は $\mathrm{Zn}$

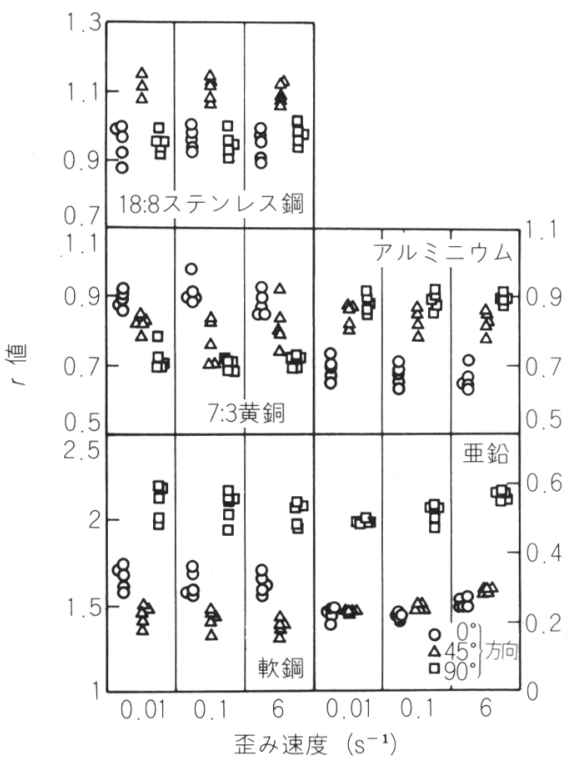

図 8 各種材料の $r$ 值の歪み速度依存性
で若干認められる程度である，Znの変化は双晶変形の 増加によつている.

いずれにしても引張試験などの基礎試験により材料特 性の歪み速度依存性を把握しプレス速度を選定すること が好ましい。

ところで引張試験でクロスヘッド速度が分かつたとこ ろでその試片の歪み速度が決まらないのと同様に，深絞 り速度が分からても素板の歪み速度は決まらない。しか し引張試験のデータをいかすためには素板の歪み速度を 知る必要がある。理論解析 ${ }^{11}$ によると最終的に最も変 形するのはカップロ縁部でこの部分は素板外周長さから カップロ縁部長さへの一軸圧縮変形なのでこの歪みを深 絞り所要時間で除して歪み速度とすることができる。そ の際，与えられた直径のカップ高さを素板の表面積と カップ表面積とが同じとして求め, それをポンチ速度で 除して所要時間とすれば良い。

\section{4. カップ表面と摩擦}

材料特性の評価に次いで避け難い厄介な塑性加工にお ける問題は使用される工具と被加工材料の界面における 摩擦の問題である。もち万んここでは摩擦そのものの話 ではなく，速度によるその変化について述べる，写真 1 は素板を絞り抜かないでポンチを途中止めしたときの カップの写真である。左は液圧プレスに該当する低速に 拈ける, 右は機械プレスに該当する高速での結果である. フランジ平坦部にあつて最も肉厚が厚いためにしわ抑え 力が集中したフランジ外縁部とダイス肩部に光沢がある のが低速カップには認められる。一方高速カップには肉 眼で見る限りこの写真のように光沢部は見られなかつ た，速度増加によつて著しく潤滑効果が高められたので ある. 写真 2 は速度による表面の変化を光学顕微鏡観察 した写真である。絞り比 $1.91(=\phi 86 \mathrm{~mm})$ のアルミニ ウムの結果である。 工具との接触を示す白地が速度とと もに減少し, 同じ速度なら粘いひまし油の方がマシン油 より白地が少ない。ところでこの低速ではひまし油の最 大絞り力の方がマシン油のそれより大きかつた。写真か

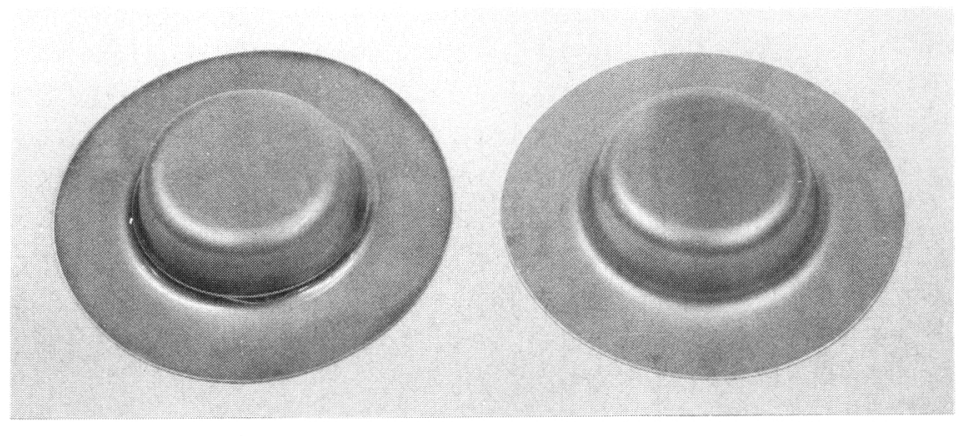

$0.05 \mathrm{~m} / \mathrm{min}$
写真 1 半絞りカップの外縁 部とダイス肩部に扔ける光沢 の速度による変化（18:8 ス テンレス鋼・ひまし油潤滑) 


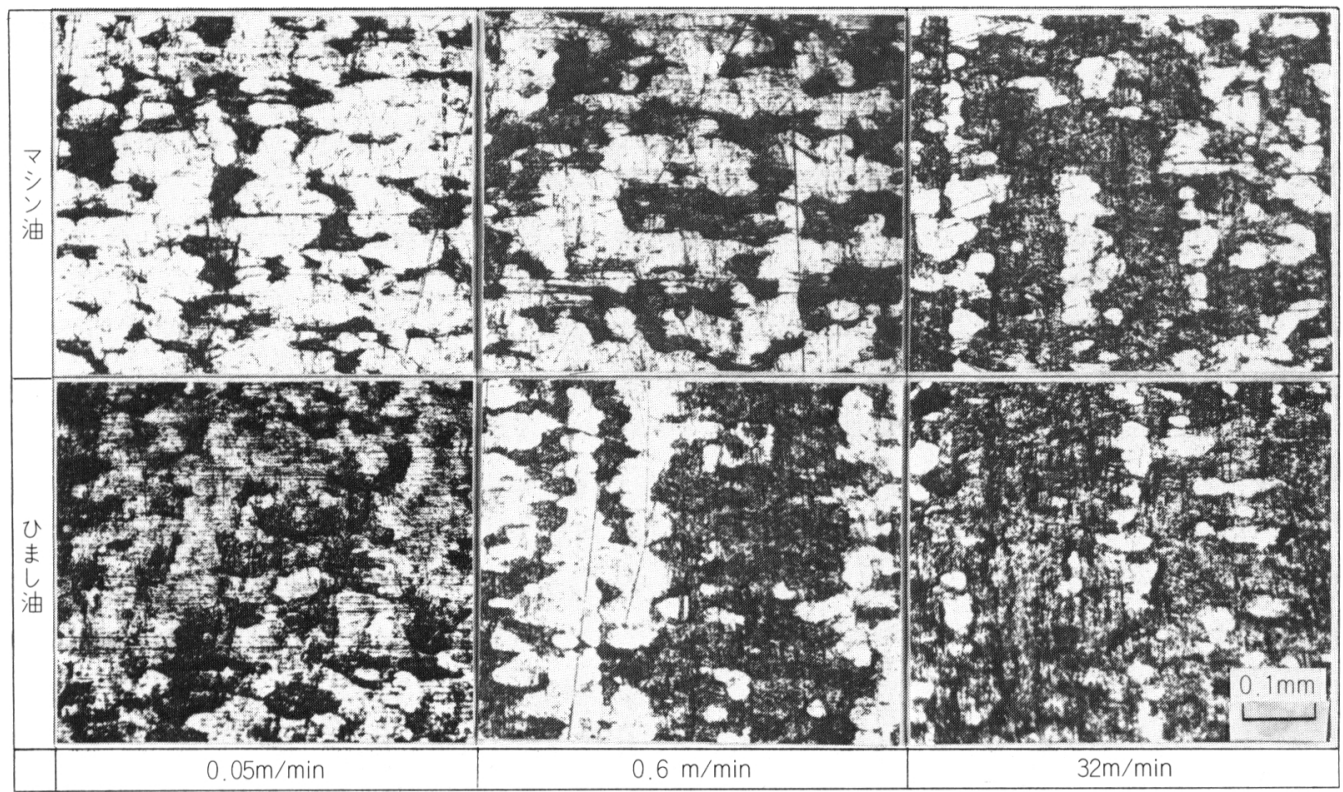

写真 2 カップ壁部表面の潤滑剤・深絞り速度による変化

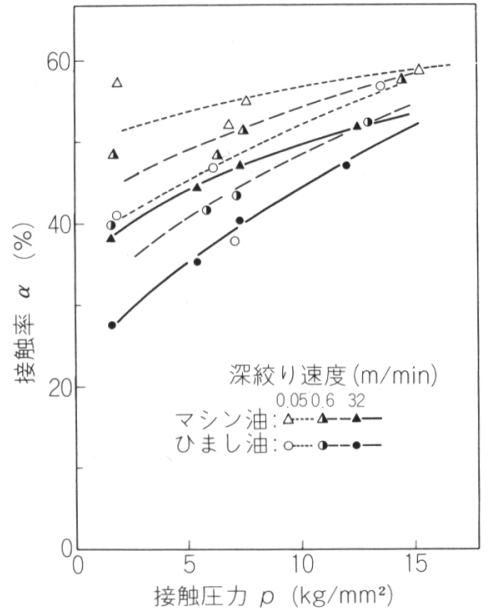

四 9 潤滑剤・深絞り速度をパラメーターとした 時の. 接触率と接触圧力の対応

ら見てひまし油の接触率はマシン油より小さいにもかか わらず，しかしひまし油の白地には無数の傷が認められ る。混合潤滑状態では接触率および接触部の閏滑性すな わち境界潤滑性の両者が重要である.

网 9 はアルミニウムから $18: 8$ ステンレス鋼と変形 抵抗の異なる 4 種類の材料について 2 種類の潤滑剤の下 に 3 水準の速度で深絞りした結果をその時の工具との面

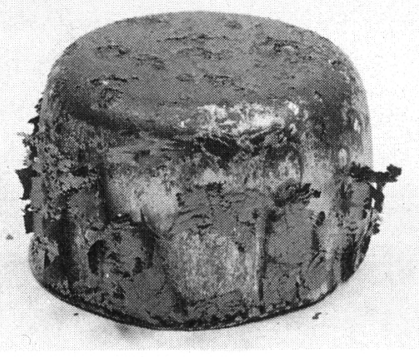

写真 3 潤滑剂である黒鉛膜をまとう絞り抜け カップ

圧に対して接触率をプロットした戝である。面圧は半実 験的に求めた值である ${ }^{12)}$ ，同速度，同潤滑剤のデー夕 がそれぞれ曲線で結んで示されている。 マシン油の低速 では圧力が減つてもほとんど接触率は小さくならない が，高速では明らかに小さくなり，ひまし油では低速で 既に面圧の減少にともなう接触率の減少が生じている. これは工具と素板の間に生じる油溜りの油に, 速度が早 くなると, そして油の粘度が増すと圧力が生じそして増 加することを示唆している。また圧力が増すにつれてあ る接触率に漸近していく傾向がある。いずれにしても速 度による潤滑性能の向上は明らかである。写真 3 はコロ イド状黒鉛の原液中に素板を浸漬し乾燥後深絞りした 


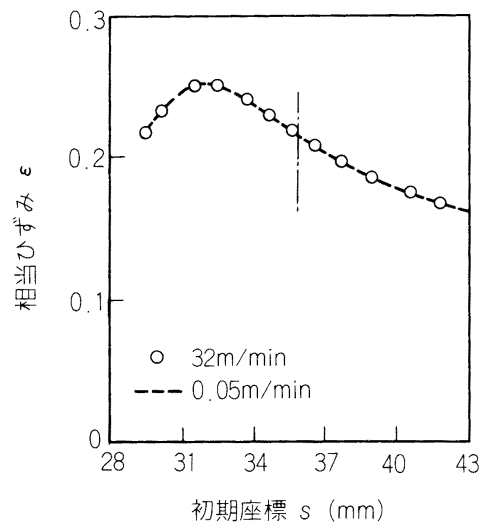

図10 カップの歪み分布におよぼす速度の影響

カップの写真である．黑鉛膜が下地素板の深絞り変形に 追随できず排除されることなく平坦フランジからカップ 壁へと運ばれている．物理的ならびに化学的吸着能いず れも無くただ素板とダイスの間に介在しているだけの小 粒は最も排除されやすいはずである。しかし面圧がかか り相対すべりが生じている状況下では異物のさらなる粉 砕そして散逸はあつても排除はむずかしい．潤滑膜の厚 みに比べて接触面の広さが極めて大きい加工法において は潤滑剤は被加工材と工具の間にトラップされるという より，むしろ排除され難くて残つているというべきであ ろう。ちなみにアルミニウムの黒鉛潤滑においてはアル ミニウムの表面の変形後の粗度は自由表面の粗度に近 い，にもかかわらず最大絞り力は他の条件のそれより大 きく,アルミニウム板および黒鉛膜，両者の深絞りにな つていたものと思われる.

ところで図 10 は変形抵抗の歪み速度依存性の大きい $\mathrm{Zn}$ 素板のフランジ部の歪み分布のプレス速度による影 響を見た図だが，まつたくその影響は認められない。と なるとプレス製品の寸法形状の違いは主に摩擦の違いに 起因したものであり，同一乙具における製品形状の違い から摩擦状況を知ることができる.

\section{5. 速度による昇温効果}

$18: 8$ ステンレス鋼の同径素板の最大絞り力そして $L D R$ における破断力は速度とともに明らかに減少する 図 6 の C-4 である. しかし図 9 の接触圧力が $12 \sim 15$ $\mathrm{kg} / \mathrm{mm}$ の $18: 8$ ステンレス鋼の接触率の速度による変 化の少なさは，速度による潤滑状態の向上ではなく材料 の速度による軟化を示唆している. 18:8 ステンレス鋼 は室温近くでも加工誘起マルテンサイトを生じオーステ ナイト状態より硬くなる，速度による最大絞り力ゃ破断 力の低下は，速度にともなう断熱昇温効果により $M d$ 点 より素板温度が上昇しマルテンサイト生成が抑えられた
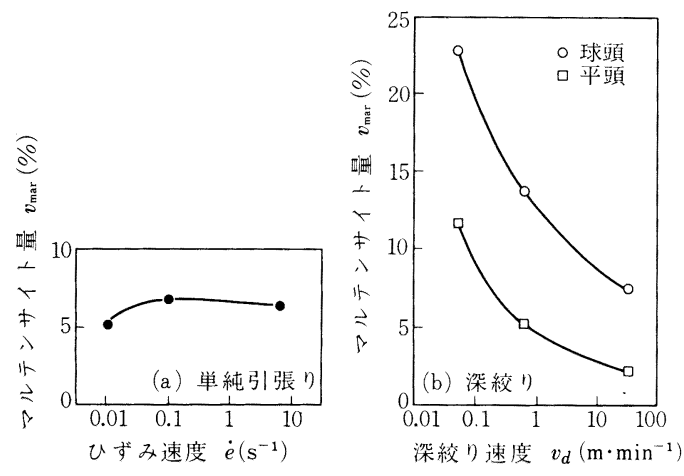

図11 18:8 ステンレス鋼の引張りと深絞り加Lに おいて生ずる加工誘起マルテンサイトの生成量と その速度依存

と考えれば説明できる.そこで破断部についてマルテン サイト量をX線回折法によりチェックしたのが泟 11 で ある. 左の引張試験では変化はないが, 布の深絞り変形 の破断部ではポンチの形状のいかんを問わず速度ととも にマルテンサイト量が急減している．耐忍力腐食割れ性 の向上など，材料サイドからすれば $18: 8$ ステンレス 鋼の成形は明らかに高速が好ましい. 問題は潤滑剂にあ る. 素板が大きくなり荷重が増すと高速では昇温のため 製品，工具とも焼付きの痕跡がはつきりしてくる．極压 添加剤の入つた油あるいはエマルジョンタイプの潤滑剤 などの使用によりこの問題は解決されるであろう.

ところで任意のある素板位置におけるある瞬間での素 板の発熱増分と工具への伝熱による消散熱減分との和で ある熱により生じる素板の温度上.昇を記述する温度の時 間と素板の位置に関する偏微分方程式を解いて, 素板や 工具に生じる温度を推測するのが一般的である。しかし 素板の各場所における塑性仕事と摩擦什事の増分を塑性 力学の助けを借りて求めるこのようなやつかいな手法は 感心しない。適当なデータから推测できる最大絞り力と 最大ポンチストロークから荷重・ストローク曲線を正弦 関数で近似しそのストローク増分に対する仕事増分から 発熱増分を求める方が良い. 近似曲線には理論で決定し 難い摩擦仕事が既に含まれているからである。それでも 工具への放熱減分については「具の温度分布が絡んでく るため簡単ではない。また金型は每回等温まで泠却され 使用されることはないから，金型の昇温を考虑した解で なくてはならない.むしろ具への伝熱を無視し，断熱 状態として素板や工具における温度の上限值を知ること の方がプレス現場では重要である。

荷重 $F$ をストローク $X$ の正弦関数で近似

$$
F=P m \cdot \sin (\pi x / h)
$$

ここで $P m$ は最大絞り力, $h$ は絞り抜けまでの最大ポン チストロータ 
ポンチがなす什事 $W$ は

$$
W=\int_{0}^{h} P m \cdot \sin (\pi x / h) d x=2 h \cdot P m / \pi
$$

この仕事はすべて素板のフランジ部の絞り込みに消費 されたとして昇温荲 $\Delta T$ を求める.

$$
\Delta T=W / A /\left(c S_{0} t_{0} \rho\right)
$$

ここで $A$ : 熱当量, $c$ : 素板の比熱, $S_{0}$ : 初期フランジ 部面積, $t_{0}$ : 初期板厚, $\rho$ : 素板の密度

上:式で权厚 $0.8 \mathrm{~mm}$ の $18: 8$ ステンレス鋼の絞り比 2 $(=\phi 90 \mathrm{~mm})$, 最大絞り力 $9330 \mathrm{~kg}$, カップ高さ $34 \mathrm{~mm}$ の昇温量は $128^{\circ} \mathrm{C}$ となつた. $18: 8$ ステンレス鋼の比熱, 密度はそれぞれ $0.51 \mathrm{~J} / \mathrm{g} \cdot \mathrm{K}, 7.93 \mathrm{~g} / \mathrm{cc}$ とした。窒温 を $20^{\circ} \mathrm{C}$ とする素板の達する温度は $148^{\circ} \mathrm{C}$ となる. この実験の潤消剤は 120 番マシン油で引火点は $150^{\circ} \mathrm{C}$, それゆえこの実験における油の焼けた臭と油煙が計算温 度の妥当性を裏付けている.

また，このように大きな昇温は材料の速度依存性の検 討に温度効果を常に考虑する必要性を示唆している. 歪 み速度の増加を温度の低下とする結晶塑性学的検討に移 る前に断熱昇温効果がクリヤされなくてはならない.

\section{6. 深絞り加工限界 $(L D R)$ の速度依存}

ところで速度による加:限界素板径の变化，すなわち $L D R$ の速度効果は材料効果なのか潤消効果なのか.

材料の重要なプレス成形特性 $r$ 值は䦷 8 で示される ようにほとんど速度依存を示さない今, 破断が生じるポ ンチ部とフランジ部における板金材の歪み速度の違いに 由来する材料効果が考えられる。 もし深絞り速度に対し てポンチ部の歪み速度がフランジの歪み速度以上に大き く変化するなら, そして $m$ 值が正で変形抵抗が歪み速 度とともに上昇するなら LDR は深絞り速度とともに増 加する. すなわち深絞り速度が増すとフランジ部の板金 要素もポンチ部の板金要素もともにその変形抵抗を増す ものの, フランジ部に対するポンチ部の相対強さが勝る からである.もちろん $m$ 值が負なら $L D R$ は深絞り速 度の上昇につれて劣下する。

ポンチ部に㧍けるカップ破断歪みは HILLの不努定条 件 ${ }^{13)}$ よりおよその見当がつく.

不安定歪みは

$$
\varepsilon=\frac{\left(x^{2}-\frac{2 r}{1+r} x+1\right)^{\frac{3}{2}}}{(x+1)\left\{x^{2}-\frac{\left(2 r^{2}+4 r+1\right)}{(1+r)^{2}} x+1\right\}} \cdot n \cdots \cdots
$$

で与えられる。ここで $x$ は応力比, $n$ は $n$ 值, $r$ は $r$ 值である. 球頭ポンチでは破断該当部は等 2 軸心力状態, 平頭ポンチでは斗百歪み状態として, それぞれ $x=1, x$ $=r /(1+r)$ を上式に代入する. 結果として

球䫒ポンチでは $\quad \varepsilon=\sqrt{2(1+r)} \cdot n$

\begin{tabular}{|c|c|c|c|c|c|}
\hline \multirow[b]{4}{*}{ 深絞り速度 } & \multicolumn{5}{|c|}{ 䄳み速度 $\left(\mathrm{s}^{-1}\right)$} \\
\hline & \multicolumn{4}{|c|}{ ポンチ张击し部 } & \multirow{2}{*}{$\begin{array}{r}\text { フランジ部 } \\
\text { 絞り比 } 2.67\end{array}$} \\
\hline & & 頭 & 球 & 頭 & \\
\hline & 理論 & 笑測 & 理論 & 実測 & 理論 \\
\hline $\begin{array}{l}0.05 \mathrm{~m} / \mathrm{min} \\
0.6 \mathrm{~m} / \mathrm{min} \\
32 \mathrm{~m} / \mathrm{min}\end{array}$ & $\begin{array}{l}0.02 \\
0.18 \\
5.6\end{array}$ & $\begin{array}{l}0.01 \\
0.15 \\
3\end{array}$ & $\begin{array}{l}0.02 \\
0.19 \\
8.7\end{array}$ & $\begin{array}{l}0.04 \\
0.3 \\
3.7\end{array}$ & $\begin{array}{l}0.03 \\
0.3 \\
12\end{array}$ \\
\hline
\end{tabular}

表 13 水準の深絞り速度におけるポンチ張出し部 とフランジ部の歪み速度の対比

$$
\text { 平頭ボンチでは } \quad \varepsilon=\frac{1+r}{\sqrt{1+2 r}} \cdot n
$$

ちなみに上式に該当 $r$ 值, $n$ 值を代入した $18: 8$ ス テンレス鋼の球頭ポンチ, 平頭ポンチでの值は 0.99 , 0.57 となり, 汹 11 のマルテンサイト量のポンチ形状に よる大小関係と良く対応し，上式による不安定歪みの值 がかなり妥当であることを示唆している. ついで $L D R$ の破断カップについて負荷開始から破断までの所要時間 によりこれら不安定歪みを除し平均歪み速度を求めた結 果が表 1 の理論と称する值である。一定深絞り速度，一 定工具条件の下では材料による歪み速度の違いはほとん ど問題にならないので, 表では 5 種類の材料の平均值が 示されている。実測はアルミニウムにストレンゲージを 貼付して求めた結果である. フランジ部における值は最 大絞り力点でのダイス面絞り方向に沿うフランジ部にお ける歪み速度分布の面積平均值で, 理論解析 ${ }^{11)}$ に基つ いている. 張出し部もフランジ部も同オーダーの歪み速 度である.フランジ部はダイス穴へと絞り込まれなくて はならず, 歪み速度は深絞り速度に比例して大きくなる. しかし張出し部はポンチに張り付いたままであり意外な 感がする。これは以下のように考えれば納得できる。最 初にポンチ部が張出されて変形硬化しフランジ部がその 強度にバランスして絞り込まれ変形硬化して停止，次に ポンチ部に変形が集中し張り出されて硬化しそれに見合 つてフランジ部がまた絞り込まれるという両部分の交互 変形を考える。そうすると両部分の歪み速度が同オー ダーであつても不思議はない.またポンチ部とフランジ 部の歪み速度が同オーダーであることは材料の機械的特 性が歪み速度により大きく変化しても, それはポンチ部 でもフランジ部でも同様に生じ結果として LDR の速度 依存が起きないことを示唆している.

材料効果が否定された今, 残るは潤滑効果であり, そ して深絞り速度に対するポンチ部の潤滑効果とフランジ 部の閏滑効果になんらかの差が生じていると考えざるを 得ない.

写真 4 は変形抵抗の大きい $18: 8$ ステンレス鋼と小 さいアルミニウムの表面状況をポンチ側から見た光学顕 微鏡写真である．ポンチ側は伸び・伸びの 2 軸張出しで フランジ側は絔み・伸び変形であるため写真 2 の表面と 

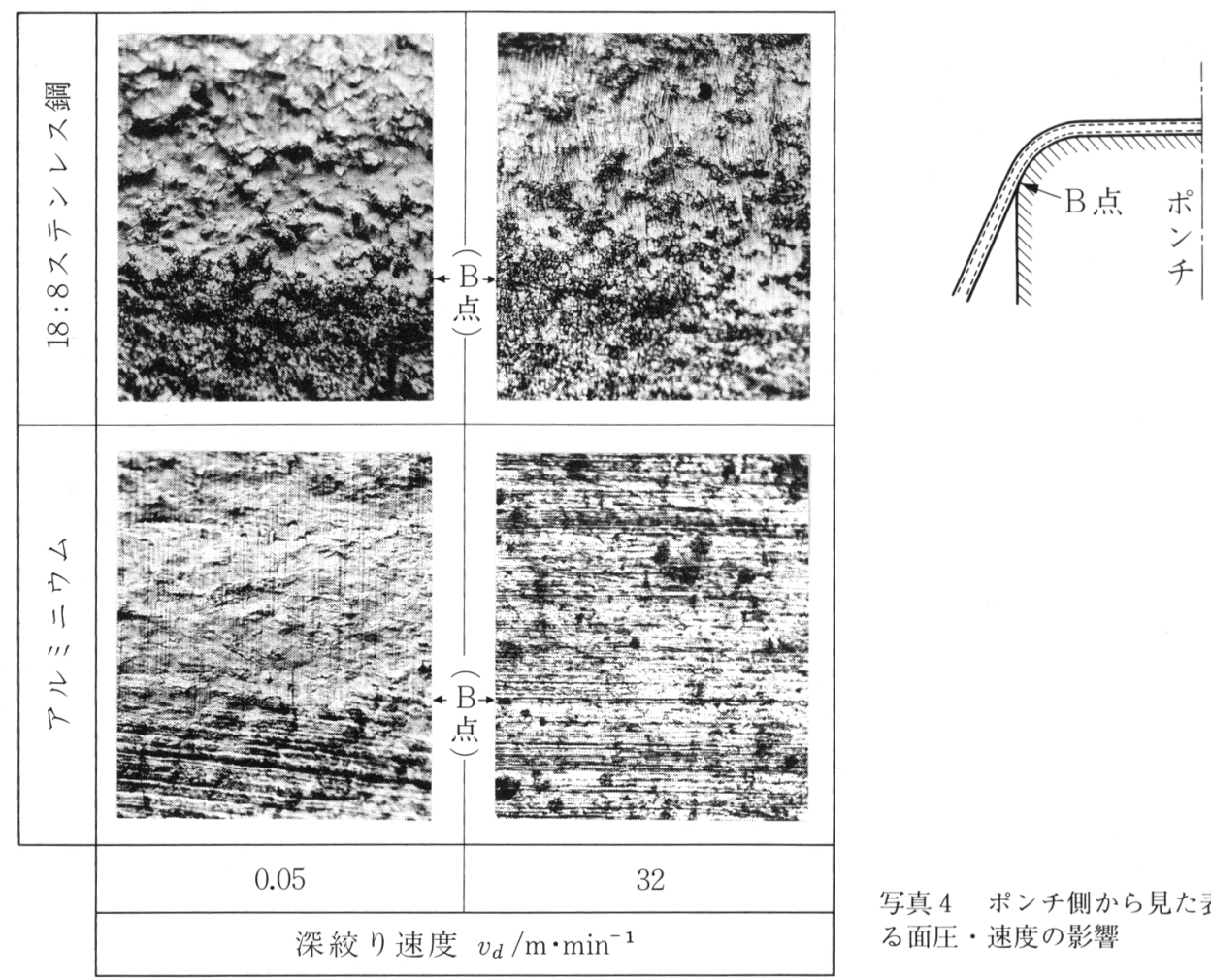

写真 4 ポンチ側から見た表面に対す る面圧・速度の影響

は様子がちがうが，ポンチ側でも同じような現象が生じ ていることをこの写真は示唆している. 18:8 ステンレ ス鋼でも B 点以下のポンチと接触していない表面に高速 になると B 点以上の接触部の表面が近づく傾向が見え， アルミニウムでは低速のB点以上のポンチによる圧下修 正面は高速では消え，素板の圧延模様すら保存されるに 至つている. しかしこのことは, 即, 摩擦力が同じであ ることを示唆するものではない.

一般に流体あるいは混合摩擦状態では $\eta V / P$ 数が重 要な変数であり，その值の増加とともに摩擦係数は小さ くなる ${ }^{14)}$. 筆者らの実験はポンチ部もフランジ部も同 じ潤滑剤が塗布されている両面潤滑条件下のものであ り，両部での粘度 $\eta$ は同じである。またそこを通つて素 板がダイス穴へ絞り込まれるダイス肩に打ける圧力 $P$ と素板をダイス穴へと押し込む圧力は作用，反作用によ りほぼ等しい，それ故， $\eta V / P$ 值が異なるとすれば，図 12 で示されるポンチ側で素板が張り出されて移動する 速度 $V_{p}$ と素板のフランジ部がダイスあるいはしわ抑え に対して動く速度 $V_{f}$ の違いであろう。そこでストレン ゲージによる歪み值から割り出したポンチ部に打ける上 限速度と理論解析から求めたフランジ部の速度をまとめ たのが表 2 である.フランジ部の大きな速度変化に対し てポンチ張出し部の速度変化は平頭ポンチ, 球頭ポンチ

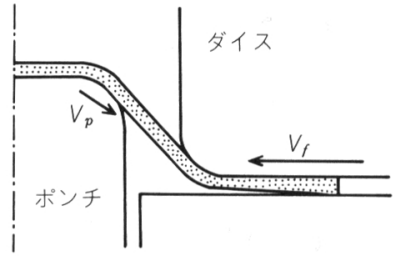

図12 素板ポンチ部とフランジ部の工具面に対する 相対速度の定義

表 23 水準の深絞り速度における工具面に対する 素板各部の相対速度

\begin{tabular}{c|c|c|c}
\hline \multirow{2}{*}{} & \multicolumn{3}{|c}{ 速度 $(\mathrm{mm} / \mathrm{s})$} \\
\cline { 2 - 4 } & タイス側 $V_{f}$ & \multicolumn{2}{|c}{ ポンチ側 $V_{p}$} \\
\hline 深絞り 速度 $(\mathrm{m} / \mathrm{min})$ & & 平頭 & 球影 \\
\hline 0.05 & 0.8 & 0.04 & 0.45 \\
0.6 & 10 & 0.59 & 3.39 \\
32 & 417 & 11.7 & 64.4 \\
\hline
\end{tabular}

とも $1 / 4$ 程度でありフランジ部の潤滑効果が速度により大 幅に改善されることが分かる。また球頭ポンチにおける 速度は平頭ポンチより常に大きく, すなわち平頭ポンチ 
より常に良潤滑状態であり，フランジ部からの力が摩擦 により遮蔽されず素板ポンチ部に伝わるため破断力が低 下し高速では $L D R$ が劣下することが分かる.すなわち 素板各部の工具に対する相対速度の違いが摩擦の違いと なり，LDRのさまざまな速度効果が惹起されるのであ る.

ところで，このような議論は現状の機械プレスの速度 範囲をしのぐ高速プレスが利用されるに至つても根本的 には同じである，既述したごとく材料特性の大きな変化 があつてもそれはポンチ部，フランジ部のいずれか一方 に生じるのではなく，両部に生じ材料効果は相殺されて しまうからである。ただし爆発成形速度に近づきすべり 変形に対する双昆変形の割合が増し, その結果 $r$ 值が 変化するなら $L D R$ は変化するけれども. それゆえ $10^{2}$ $\sim 10 \%$ 程度のひずみ速度を材料に生じしめる高速プレ スでは，高速成形下での断熱昇温による油膜の焼損を含 む潤滑効果の速度依存に依然として支配されるであろ j.

\section{7. 総 括}

深絞り加ににおける速度効果はポンチ部とフランジ部 の両者の競合によつて律せられるこの独特の加工法にか らんだ潤滑効果の速度依存によつている。速度とともに 加工限界が向上するもの, 劣下するもの, ポンチ荷重が 増すもの, 減るもの等, 13 種類もの夕イプの速度効果 があり，生産現場ではどの夕イプに担当プレス品が該当 するか見きわめ適切な速度を選ぶ必要がある。 あるいは 潤滑剤の変更，製品形状の修正等により，より好ましい
タイプに近づけるよう努力すべきである，熱活性化過程 が多少複雑で材料特性の歪み速度依存がはつきりせず機 械プレス程度の速度でも伸びが急減しそうな材料以外は 高速成形は推奨される. 特に断熱昇温による軟化が起こ る $18: 8$ ステンレス鋼では速度増加によるポンチ荷重 の減少そして成形後の品質上からも高速でプレスするこ とが好ましい。

終わりに, 結晶塑性の歪み速度依存について有益な助 言を承つた大阪大学工学部金属材料工学科, 山口正治助 教授にお礼申し上げます。

\section{文献}

1 ) 小林徳大, 村田庫一, 石垣秀生: 塑性と加工, 9 (1968), p. 451

2) H. T. Coupland and D. V. Wilson: Sheet Metal Industory, 35 (1958), p. 85

3 ) 花木香司, 中川 晃, 松村光展, 加藤健三: 塑性と加工, 17 (1976), p. 45

4 ) W. J. M. TEGART: 金属の力学的性質 (1966), p. 39 [丸善]

5 ) T. V. Karman and P. Duwez: J. Appl. Phys. 21 (1950), p. 987

6 ) 福井伸二, 河田幸三, 清野次郎: 東京大学航空研究所集報, 3 (1963), p. 361

7 ) 周藤悦郎, A. HANSSON: 塑性と加工, 11 (1970), p. 351

8 ) 花木香司, 加藤健三: 日本金属学会誌, 47 (1983), p. 533

9) A. K. GHoSH: Trans. ASME, 7 (1977), p. 264

10）酒井賢一郎: 塑性と加工, 13 (1972), p. 542

11）花木香司，加藤健三: 塑性と加工， 21 (1980), p. 422

12）花木香司，加藤健三: 塑性と加工， 22 (1981), p. 49

13) R. Hill: J. Mech. Phys. Solids, 1 (1952), p. 19

14）例えば $H$. ChristensEN: Proc. Instn. Mech. Engrs, 186 (1972), p. 421 